\title{
City Logistics Measures and Environmental Sustainability: An Evidence from Ghana
}

\author{
Adzani Sophia Akosua*, Xiaoyan Yang, Mintah Clement, Abdul-Hamid Zalia, \\ Baba Vanessa Fathia
}

School of Economics and Management, Taiyuan University of Technology, Taiyuan, China

Email: *sophiaadzani@ymail.com, guloulansx@163.com, yawmintahclement@gmail.com, zaliaabdulhamid96@gmail.com, vanessafathia@gmail.com

How to cite this paper: Akosua, A. S., Yang, X. Y., Clement, M., Zalia, A.-H., \& Fathia, B. V. (2021). City Logistics Measures and Environmental Sustainability: An Evidence from Ghana. American Journal of Industrial and Business Management, 11, 582-597.

https://doi.org/10.4236/ajibm.2021.115037

Received: April 26, 2021

Accepted: May 25, 2021

Published: May 28, 2021

Copyright $\odot 2021$ by author(s) and Scientific Research Publishing Inc. This work is licensed under the Creative Commons Attribution International License (CC BY 4.0).

http://creativecommons.org/licenses/by/4.0/

\begin{abstract}
This paper analyzed the relationship between city logistics measures and environmental sustainability in Ghana. This paper analysis followed an established pattern using the Multiple Linear Regression (MLR) model and correlation matrix. After estimating the descriptive statistics covering four (4) variables such as environmental sustainability, policy, stakeholders interaction, and city logistics measures. The findings indicated that policies correlated with city logistics measures (21\%) and environmental sustainability (84\%) at $1 \%$ significant levels; furthermore, at a $1 \%$ significant level, the policies correlated strongly with environmental sustainability than the other variables. The results show that policies play a crucial role in environmental sustainability. The test values indicate that SI, SII and CLM are statistically significant at $p$ $(0.000)<0.05$ respectively whereas $\mathrm{P}, \mathrm{P} 1$, SI2 and CLM1 are not statistically significant at $p(0.293)>0.05, p(0.779)>0.05, p(0.577)>0.05$ and $p$ $(0.351)>0.05$. Even though the $\mathrm{P} 2$ value is significant, $p(0.031)<0.05$. The impacts on environmental sustainability are not felt much. But more importantly, SI and CLM have a positive influence on environmental sustainability. Hence, hypotheses ( $\mathrm{H} 1, \mathrm{H} 2$, and $\mathrm{H} 3$ ) were accepted. These then call for policy direction on city logistics measure implementation and environmental sustainability in Ghana and other parts of the world.
\end{abstract}

\section{Keywords}

City Logistics, Policies, Stakeholder Involvement, Environmental Sustainability

\section{Introduction}

Although urban transportation is significant in developing an economy and meet- 
ing citizens' needs, it has a considerable effect on livability in cities; hence protecting the environment is crucial. Rapid urbanization drift is emptying the rural area and making cities larger with an increase in demand for goods; this rapid growth is expected to reach $85 \%$ by 2050 (OECD, 2003). Cities, thus are facing a slew of problems, including traffic congestion, noise, and air pollution, adverse environmental effects and energy use, and a lack of public space (Cobbinah et al., 2015, Russo and Comi, 2016, Cobbinah et al., 2017, WHO, 2018). These environmental nuisances affect city resident's quality of life, as well as the productivity of businesses in city areas and the distribution networks. They contribute to the perception that urban areas are unhealthy, causing many people to flee the city in search of a more environmentally friendly climate (Benjelloun \& Crainic, 2009).

Taniguchi et al. (2012), the environmental effect of urban freight transport is becoming troubling as population growth and urban congestion increase; hence the requisite need for sustainable urban development and the coordination of traffic flow and logistics is gradually on the rise in other to address environmental problems. The conception of city logistics has evolved to address these issues by providing solutions and methods to assist various decision makers in urban transport, and management for the economic and social growth of the cities (Taniguchi et al., 2001; Taniguchi \& Thompson, 2018). City logistics is therefore described as the process of private companies ultimately enhancing their transport and logistics operations in city areas using information technologies while taking into account the traffic climate, congestion, and energy usage within the context of an economy (Taniguchi et al., 2001).

The definition further elaborates on the context of energy consumption given the negative impacts produced by logistic vehicles in urban zones, such as urban noise pollution, $\mathrm{CO}_{2}$ emissions, and vibration espoused by (Taniguchi, 2014). Furthermore, Demir et al. (2015) explained in their paper that city logistics involves not only the variety of goods conveyed and the classification of transport modes but rather the participation of decision makers in the design and implementation of strategies. Typically, these stakeholders have different goals and objectives, and their viewpoints are critical in the development of urban policy. For achieving sustainable urban freight growth, the essence of partnership and collaborative work between urban decision makers has been acknowledged by (Crainic et al., 2009; Österle et al., 2015).

Again, (Allen et al., 2000; Lindholm and Blinge 2014) noted, to gain a deeper understanding of urban freight transportation challenges and perceptions of individuals on urban transportation functionality, national and local authorities should therefore involve the private sector in freight planning. As a result, (Valiantis, 2014, UN, 2019) stated that the core idea for sustainable city logistics is its social, economic, and environmental aspects.

More importantly, regarding the launch of the Brundtland Commission (Keeble, 1988), that described sustainable development as strategies that satisfies the present needs without jeopardizing future generation's capacity to satisfy their 
own needs. Environmental sustainability has become a notable subject of concern for policymakers and city planners in both developed and developing economies. That said, (Katsela and Browne, 2019, Van Duin et al., 2019) environmental sustainability goals can be embrace through indicators which are often contradictory and produce outcomes that are dependent on the acknowledgment of stakeholder groups along with external influences. In this context, organizations worldwide highlight the essence for caring for the environment as a vital precondition for sustainable development (Schaltegger et al., 2012).

The study's purpose was to determine the influence of city logistics measures on environmental sustainability in Ghana. The author attempted to verify the hypothesis: There is a significant relationship between city logistics measures and environmental sustainability.

The paper is structured as follows: we presented the concept of city logistics and environmental sustainability clearly to provide the framework. Section 2 provides a summary of the actors involved in the city logistics with their viewpoints and motives. Section 3 focuses on city logistics measures implemented and their influence on environmental sustainability (general positive and negative impact concerning the environment). Afterward, section four describes the methodology used. The following section presented the analysis and results of the data in the paper. The paper ends with conclusions, and future research.

\section{City Logistics Actors}

For several years, the area of city logistics has been researched by many scholars. However, it is still evolving due to changes in the climate and resident habits (Anand et al., 2012, Taniguchi et al., 2014, Lagorio et al., 2016). Since city logistics is primarily concerned with freight movement, it is expected to be of relevance to private corporations. More recent definitions of city logistics are general, viewing it as a method of integrating all movements within urban centers, including freight and passenger flows (Quak et al., 2014, Behrends, 2016, Lagorio et al., 2016). Passenger mobility, which is linked primarily to public transportation in urban areas, is intrinsically coordinated by the public sector; thus, city logistics, which covers freight and individual flow, needs the attention of both decision makers. Considering the strong relations between city logistics and planning, cooperation in the city process while considering mobility problems is essential. As a result, all participants in the urban transportation system need to be recognized. As illustrated by (Witkowski \& Kiba-Janiak, 2012, Demir et al., 2015, Neghabadi et al., 2018), diverse stakeholders with different viewpoints and priorities are also intrinsic characteristics of city logistics. These stakeholders functioning in cities communicate simultaneously by competing and collaborating, and their decisions do not interrupt them (Zenezini et al., 2018). Hence their involvement is crucial for carrying out the primary operations of city logistics measures (Awasthi and Proth, 2006, Gatta et al., 2018).

According to (Taniguchi et al., 2001, Benjelloun et al., 2010, de Oliveira and de Oliveira, 2016), city logistics key actors can be into groups; shippers, admin- 
istrators, freight carriers, and residents. These actors can generally be groups: private and public stakeholders. Lindholm and Behrends (2012) considered the administrator (national and local government) as the public stakeholders while shippers, freight carriers, and residents (entrepreneurs) were group under the private stakeholders (Rześny-Cieplińska and Szmelter-Jarosz, 2020). The priorities of each of these stakeholders with respect to urban logistics are different. They have a significant part in city logistics measures (Katsela and Browne, 2019); for instance, administrators are primarily concerned with improving road traffic safety and reducing congestion and environmental pollution (Benjelloun et al., 2010, Pimentela \& Alvelos, 2018). Shippers, on the other hand, are solely interested in optimizing service efficiency in terms of cost and transport reliability (Carbone et al., 2017). The main resident priority is to have a comfortable living environment, accomplished by reducing traffic congestion and travel time through the urban area and lowering $\mathrm{NOx}, \mathrm{CO}_{2}$ emissions, and other harmful substances. Freight carriers are focused on reducing costs by increasing the reliability of their delivery and distribution paths (Quak et al., 2016).

For the planning of various city logistics activities and implementing city logistics measures (Taniguchi \& Tamagawa, 2005, Le Pira et al., 2017, Oliveira et al., 2018, Rześny-Cieplińska and Szmelter-Jarosz, 2021), modeling the actions, goals, and the interaction of stakeholders has become critical. Researchers (Lebeau et al., 2018, Gatta et al., 2019) indicated that stakeholder's involvement could contribute towards sustainable urban development; thus, adequate urban infrastructure, enhance low-impact urban design and transportation networks. Also, the need for shared motives and priorities by stakeholders involved is a crucial element for implementing city logistics measures (Awasthi and Proth, 2006, Lindholm \& Browne, 2013, Quak et al., 2016), as their interaction influence their behavior during the implementation process. Again, (Stathopoulos et al., 2012; Marcucci et al., 2017; Marcucci et al., 2018; Gatta et al., 2019), the interaction of stakeholders is a factor in the success of city logistics measures, without a mutual understanding amongst actors, it may be challenging to attain sustainable city logistics initiatives. Hence their interaction leads to efficient and effective city logistics measures.

\section{City Logistics Measures, Environmental Sustainability and Hypotheses}

Over the years, environmental pollution has been a critical problem circulated across the world. The implementation of city logistics initiatives such as stakeholder interaction, regulatory, market-based schemes, land management, technological advancements, and eco-logistics recognition was done in most of the European countries to address the challenges. Research shows no single approach can highlight and solve all urban freight transport issues since the issues differ from cities to cities, but collaborative efforts can yield better results.

According to (CIVITAS, 2020) practical example is Barcelona urban projectsCivitas Miracle 2002-2006. The implementation of night-time deliveries using mo- 
dified trucks and quiet discharging methods showed that the initiative achieved its objectives of reducing delivery times, lowering transport operating costs, reduce congestion and emissions, and last-mile delivery systems.

More so, Pustokhina \& Pustokhin (2019) examines the history of car sharing in Russia, its benefits and shortcomings, and car-sharing operators in Moscow. They conclude that the car-sharing system contributes to improving the transportation network and the environment, thereby tackling sustainable urban development problems. Another scholar, (Taniguchi \& Tamagawa, 2005) findings show that implementing a truck ban and toll collection of city expressways as a city logistics measure did not precisely improve all stakeholder conditions. It was positive for them in general since it impacted dispersing the areas where residents complained and ensuring an equitable environment. Lidasan (2011) also debunked that city logistics policy contributes to minimising the adverse environmental effects of urban transportation.

Furthermore, city logistics measures studied for the Brazilian context (de Oliveira \& de Oliveira, 2016) show a high acceptance rate by carriers and the administration. Retailers, on the other hand, seem to be resistant to any proposed system. This dissent could be the outcome of insufficient knowledge about the positive impact of the measures. Nevertheless (Rześny-Cieplińska \& SzmelterJarosz, 2020) concluded that the establishment of legal restrictions and infrastructure successfully reduced the negative effect of urban freight transportation in Polish cities of Gdansk, Sopot, and Gdynia.

Lastly, Sarbah et al. (2014) conclude their research by indicating that, despite the positive impacts, there were still adverse effects associated with traffic congestion, a lack of energy consumption, noise, and air pollution in Ghana cities.

We draw the following hypothesis based on the above literature review;

$\mathrm{H1}$ : There is a significant relationship between city logistics measures and environmental sustainability

$\mathrm{H} 2$ : Stakeholder interaction impacts city logistics measures implementation.

H3: Policies influence city logistics measures.

\section{Methodology}

The survey methodology was used in the study, and we design questionnaires to obtain respondent views of the enactment of city logistics measures and their benefits to environmental sustainability. We used a point Likert scale ranging from 1 (strongly disagree) to 5 (strongly agree) to assess the variable's significance and identify respondent opinions on city logistics and environmental sustainability. Likert (1932) developed the theory of measuring attitudes by asking respondents to rate several statements about a topic based on how much they consented with them, thereby tapping into their perspectives. This ordinal scale was to assess levels of agreement, disagreement. The author used an electronic questionnaire in a google form. The researcher used close-ended questions to conduct the survey. However, we were able to collect responses automatically 
through emails, and whatsapp platforms. The questions were in two folds; socio-demographic characteristics of respondents were studied and other four variables were also measured.

Subsequently, a target population of nine hundred (900) respondents were estimated. Out of which two hundred and seventy-six (276) respondents were selected randomly using stratified random sampling technique. The sample size was determined using (Yamane, 1967) formulae represented below.

$$
n=\frac{N}{1+N(\alpha)^{2}}
$$

Given that:

- Desired sample size is represented by $n$

- margin of errors (0.05) at $95 \%$ level of confidence is represented by a

- The constant ure is 1

- Total population is represented by $N$

$$
\begin{aligned}
& n=\frac{900}{1+900(0.0025)} \\
& n=\frac{900}{1+2.25} \\
& n=\frac{900}{3.25} \\
& n=276.923
\end{aligned}
$$

The study also employed the Pearson correlation matrix to establish the relationship between city logistics measures and environmental sustainability. To established linearity between the four (4) variables, the multiple linear regression models were estimated where environmental sustainability became the dependent variable with other variables such as policies, stakeholder involvement, and city logistics measures as the independent variable in model specification. The idea was to compare how much each of the independent variables influences the model's dependent variables. The data revealed that there is a unit change in the independent variable on the dependent variables. The model used is illustrated below;

The general form of our empirical VAR can be modeled as;

$$
\mathrm{ES}=\alpha+\beta_{1} \mathrm{P}+\beta_{2} \mathrm{SI}+\beta_{3} \mathrm{CLM}+\varepsilon
$$

where; $\alpha=$ Constant, $\beta=$ Change in variable

ES $=$ Environmental sustainability, $\mathrm{P}=$ Policy, $\mathrm{SI}=$ Stakeholder interaction, CLM $=$ City Logistics Measures.

\section{Empirical Results and Discussions}

\subsection{Descriptive Statistics of Respondents}

Table 1 shows the results of descriptive statistics performed on data from our survey participants. According to the findings, most of our respondents were females accounting for $58 \%$, while $42 \%$ were males. $10.9 \%$ were between the ages of $20-30,61.1 \%$ between the ages of $31-40,19.6 \%$ the ages of $41-50,4 \%$ be- 
tween the ages of $51-60$, and above 60, respectively. In the stakeholder category, $65.6 \%$ of participants were from the private sector, while $34.4 \%$ were in the public sector. $22.1 \%$ accounted for the shipper group, $15.6 \%$ being administrators, $29.3 \%$ representing freight carriers, $17.8 \%$ were in the resident group, and $15.2 \%$ in the transport operator group.

\subsection{Reliability and Validity Test}

The accuracy and consistency of a survey question are important in research (Taherdoost, 2016); hence reliability and validity test was carried out. We use Cronbach's Alpha to estimate the assessment tool's internal consistency. Cronbach's Alpha is a consistency coefficient that denotes how well items in the questionnaire are significantly correlating to one another, with a score of 1 indicating greater internal consistency and reliability and a score of 0.7 to 0.9 indicating acceptable internal consistency and reliability (Zinbarg et al., 2005). The result in Table 2 shows that the number of items tested had a Cronbach's Alpha of.801, which is highly reliable and required no further modification. It indicates that the survey questions used in each variable of the research were reliable.

We then carried out a factor analysis for the construct validity test. To measure the significance of the connection between the variables, we used Kaiser Meyer Olkin (KMO) and Bartlett's Test. Kaiser (1974), suggested 0.5 (value for $\mathrm{KMO}$ ) as the least level (which is acceptable), KMO value between $0.7-0.8$ as appropriate, and values are above 0.9 as outstanding. According to the table below, our KMO measure is 0.914 within the range of KMO values greater than 0.9 and exceptional (Table 3 ).

Table 1. Descriptive statistics.

\begin{tabular}{ll}
\hline Category & Respondents \\
\hline Gender & Male (116 persons, 42\%), Female (160 persons, 58\%) \\
Age & $\begin{array}{l}21-30 \text { (30 persons, 10.9\%), 31- } 40 \text { (170 persons, 61.6\%), } 41-50 \text { (54 persons, } 19.6 \%), 51-60 \text { and } 60+(11 \text { persons, } \\
4 \% \text { respectively) }\end{array}$ \\
Stakeholders Category & Private Sector (181 persons, 65.6\%), Public sector (95 persons, 34.4\%), \\
Stakeholders group & $\begin{array}{l}\text { Shippers (61 persons, 22.1\%), Administrators (43 persons, 15.6\%), Freight Carriers (81 persons, 29.3\%), } \\
\text { Residents (49 persons, 17.8\%), Transport Operators (42 persons, 15.2\%) }\end{array}$ \\
\hline
\end{tabular}

Table 2. Reliability test result.

\begin{tabular}{cc}
\hline Cronbach's Alpha & N of Items \\
\hline 0.801 & 17 \\
\hline
\end{tabular}

Table 3. KMO and bartlett's test.

\begin{tabular}{ccc}
\hline Kaiser-Meyer-Olkin Measure of Sampling Adequacy. & & $0.914^{*}$ \\
\hline Bartlett's Test of Sphericity & Approx. Chi-Square & 3038.376 \\
& Df & 55 \\
\hline
\end{tabular}


The same table shows that Bartlett's Test of Sphericity is significant $(<0.05), p$ $<0.000$ signifying that the correlation matrix varies substantially from an identity matrix. All correlations amongst variables are zero. The approximate Chisquare test of sphericity was 3038, with a difference of 55 .

\subsection{Correlation Matrix}

To assess the significance of the relationships between the variables in our model (Obilor \& Amadi, 2018), we conducted a correlation analysis using the Pearson coefficient. The results are presented in Table 4.

Table 4 shows that policies positively correlated to city logistics measures and environmental sustainability. Policies correlated with city logistics measures (21\%) and environmental sustainability (84\%) at $1 \%$ significant levels. Furthermore, at the $1 \%$ significant level, the policies correlation was much more substantial with environmental sustainability than the other variables, indicating the crucial roles policies play in the sustainable development of a city. Policies were correlating with stakeholder interaction at a 5\% significant level with $12 \%$. Stakeholder interaction correlated with policies and environmental sustainability at $5 \%$ significant levels, respectively (12\% and $15 \%)$. However, Stakeholder interaction correlated positively with city logistics measures at a $1 \%$ significant level (49\%), signifying importance. City logistics measures are strongly related to policies, stakeholder interaction, and environmental sustainability at $21 \%, 49 \%$, and $24 \%$ (1\% significant levels), respectively. Environmental sustainability strongly correlated with policies and city logistics measures at $84 \%$ and $24 \%(1 \%$ significant levels), respectively. However, environmental sustainability correlated with stakeholder involvement at a 5\% significant level (15\%).

The statistical analysis drawn from the correlation matrix confirms the other research findings of $\mathrm{H} 1, \mathrm{H} 2$, and $\mathrm{H} 3$ that there is a significant relationship between city logistics measures and environmental sustainability at a $1 \%$ significant level. Again, stakeholder interaction impacts city logistics measures implementation. Therefore, the alternative hypothesis are accepted under the correlation matrix (Witkowski \& Kiba-Janiak, 2012, Rubinia \& Lucia, 2018). Lastly, based on hypothesis three (H3), policies influence city logistics measures as espoused by (Lidasan, 2011), we, therefore, accept the hypothesis.

\subsection{Regression Analysis}

Using multiple linear regression (MLR), we analyze how well the independent variables were associated with a dependent variable of interest. The results are present in Tables 5-8.

Tables 5-8 indicate that the R-value of 0.920 shows a good level of prediction. The $\mathrm{R}$ square value of 0.846 shows that our independent variable explains $84.6 \%$ of our dependent variable's variability (environmental sustainability). Hence, $15 \%(100 \%-85 \%)$ variation is caused by factors other than predictors included in this model. The adjusted $\mathrm{R}$ square value of 0.841 indicates $84.1 \%$ of the variation in the outcome variable explained by the independent variables. 
Table 4. Pearson's correlation coefficient.

\begin{tabular}{|c|c|c|c|c|c|}
\hline & & $\mathrm{P}$ & SI & CLM & ES \\
\hline \multirow[t]{3}{*}{$\mathrm{P}$} & Pearson's correlation & 1 & $0.119^{*}$ & $0.205^{\star *}$ & $0.840^{* *}$ \\
\hline & sig. (2 tailed) & & 0.049 & 0.001 & \\
\hline & $\mathrm{N}$ & 276 & 276 & 276 & 276 \\
\hline \multirow[t]{3}{*}{ SI } & Pearson's correlation & $0.119^{*}$ & 1 & $0.491^{\star *}$ & $0.147^{\star}$ \\
\hline & sig. (2 tailed) & 0.049 & & & 0.015 \\
\hline & $\mathrm{N}$ & 276 & 276 & 276 & 276 \\
\hline \multirow[t]{3}{*}{ CLM } & Pearson's correlation & $0.205^{\star *}$ & $0.491^{* *}$ & 1 & $0.239^{* *}$ \\
\hline & sig. (2 tailed) & 0.001 & & & \\
\hline & $\mathrm{N}$ & 276 & 276 & 276 & 276 \\
\hline \multirow[t]{3}{*}{ ES } & Pearson's correlation & $0.840^{* *}$ & $0.147^{\star}$ & $0.239^{* *}$ & 1 \\
\hline & sig. (2 tailed) & & 0.015 & & \\
\hline & $\mathrm{N}$ & 276 & 276 & 276 & 276 \\
\hline
\end{tabular}

${ }^{*}$ Correlation is significant at the 0.01 level (2-tailed). ${ }^{\star}$ Correlation is significant at the 0.05 level (2-tailed).

Table 5. Model summary.

\begin{tabular}{ccccccccccc}
\hline Model & $\mathrm{R}$ & $\mathrm{R}$ Square & Adjusted R Square & Std. Error of the Estimate & Change Statistics & & & \\
\hline & & & & & R Square Change & F Change & df1 & df2 & Sig. F Change \\
1 & $0.920^{\mathrm{b}}$ & 0.846 & 0.841 & 0.453 & 0.846 & 182.766 & 8 & 267 & 0.000 \\
\hline
\end{tabular}

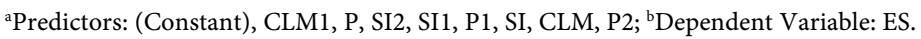

Table 6. ANOVA.

\begin{tabular}{ccccccc}
\hline Model & & Sum of Squares & Df & Mean Square & F & Sig. \\
\hline 1 & Regression & 300.229 & 8 & 37.529 & 182.766 & $0.000^{\mathrm{b}}$ \\
& Residual & 54.825 & 267 & 0.205 & & \\
& Total & 355.054 & 275 & & & \\
& & & & & \\
\hline
\end{tabular}

'Predictors: (Constant), CLM1, P, SI2, SI1, P1, SI, CLM, P2.

Table 7. Coefficients.

\begin{tabular}{|c|c|c|c|c|c|c|c|c|c|c|c|}
\hline \multirow[t]{2}{*}{ Model } & & & & $\begin{array}{l}\text { Standardized } \\
\text { Coefficients }\end{array}$ & $\mathrm{T}$ & Sig. & \multicolumn{2}{|l|}{ Correlations } & \multicolumn{3}{|c|}{$\begin{array}{l}\text { Collinearity } \\
\text { Statistics }\end{array}$} \\
\hline & & & & Beta & & & Zero-order & Partial & Part & Tolerance & VIF \\
\hline \multirow[t]{9}{*}{1} & (Constant) & -0.044 & 0.148 & & -0.294 & 0.769 & & & & & \\
\hline & $\mathrm{P}$ & 0.052 & 0.049 & $0.042^{\star}$ & 1.053 & 0.293 & $0.643^{*}$ & 0.064 & 0.025 & 0.358 & $2.796^{*}$ \\
\hline & $\mathrm{P} 1$ & 0.014 & 0.052 & $0.013^{*}$ & 0.281 & 0.779 & 0.706 & 0.017 & 0.007 & 0.280 & $3.577^{*}$ \\
\hline & $\mathrm{P} 2$ & 0.130 & 0.060 & $0.127^{\star}$ & 2.165 & 0.031 & 0.848 & 0.131 & 0.052 & 0.168 & $5.969^{*}$ \\
\hline & SI & 0.207 & 0.053 & $0.209^{*}$ & 3.888 & 0.000 & 0.850 & 0.232 & 0.094 & 0.201 & $4.977^{*}$ \\
\hline & SI1 & 0.205 & 0.051 & $0.215^{\star}$ & 4.041 & 0.000 & 0.850 & 0.240 & 0.097 & 0.203 & $4.915^{*}$ \\
\hline & SI2 & 0.008 & 0.014 & $0.016^{*}$ & 0.558 & 0.577 & 0.133 & 0.034 & 0.013 & 0.744 & $1.344^{*}$ \\
\hline & CLM & 0.383 & 0.059 & $0.376^{*}$ & 6.495 & 0.000 & 0.888 & 0.369 & 0.156 & 0.173 & $5.794^{*}$ \\
\hline & CLM1 & 0.015 & 0.016 & $0.026^{*}$ & 0.935 & 0.351 & 0.199 & 0.057 & 0.022 & 0.732 & $1.366^{*}$ \\
\hline
\end{tabular}

${ }^{*}$ Dependent Variable: ES. 
Table 8. Residuals statistics.

\begin{tabular}{|c|c|c|c|c|c|}
\hline & Minimum & Maximum & Mean & Std. Deviation & $\mathrm{N}$ \\
\hline Predicted Value & 1.03 & 5.05 & 4.12 & 1.045 & 276 \\
\hline Std. Predicted Value & -2.954 & 0.895 & 0.000 & 1.000 & 276 \\
\hline Standard Error of Predicted Value & 0.040 & 0.212 & 0.076 & 0.031 & 276 \\
\hline Adjusted Predicted Value & 1.03 & 5.05 & 4.12 & 1.049 & 276 \\
\hline Residual & -1.656 & 2.442 & 0.000 & 0.447 & 276 \\
\hline Std. Residual & -3.654 & $5.389^{*}$ & 0.000 & 0.985 & 276 \\
\hline Stud. Residual & -3.716 & 6.097 & 0.004 & 1.023 & 276 \\
\hline Deleted Residual & -1.712 & 3.126 & 0.004 & 0.483 & 276 \\
\hline Stud. Deleted Residual & -3.808 & 6.560 & 0.006 & 1.040 & 276 \\
\hline Mahal. Distance & 1.121 & 59.206 & 7.971 & 8.004 & 276 \\
\hline Cook's Distance & 0.000 & $1.158^{*}$ & 0.010 & 0.072 & 276 \\
\hline Centered Leverage Value & 0.004 & 0.215 & 0.029 & 0.029 & 276 \\
\hline
\end{tabular}

${ }^{*}$ Dependent Variable: ES.

Table 6 attempts to evaluate the overall goodness of fit of the fitted multiple linear regression. According to the above table, the general model is statistically significant because the $P$-value of F statistics is 0.00 , which is less than the significance level (0.05).

Table 7 illustrates a statistically significant of the dependent variable on the independent variables such as SI, SI1, and CLM. The test values indicates that SI, SI1 and CLM are statistically significant at $p(0.000)<0.05$ respectively whereas $\mathrm{P}, \mathrm{P} 1, \mathrm{SI} 2$ and CLM1 are not statistically significant at $p(0.293)>0.05, p$ $(0.779)>0.05, p(0.577)>0.05$ and $p(0.351)>0.05$. Even though the $\mathrm{P} 2$ value is significant $p(0.031)<0.05$, its environmental sustainability impacts are not felt much. But more importantly, SI and CLM have a positive influence on ES. On the other hand, the collinearity with variance inflation of values is less than 10 , which divulges that there is no multicollinearity diagnostic in the data set.

The standard residual value $(-3.654)$ of the predicted variables on the dependent variable in the preceding table indicates that the data set is not normally distributed. When plotted, the standard residual value exceeds -3 to 3 . However, Cook's distance, which has the highest value (1.158) of all predictor variables, in this case, indicates that it influences the dependent variable.

\section{Conclusion and Recommendation}

The topic of city logistics measures implementation and environmental sustainability continues to be a critical area that requires more research, toppled with practical solutions to lessen its negative impact on the environment. The implementation of city logistic measures is one of the most significant areas to be examined in academic discourse. Hence, perceived as a multi-dimensional concept that encompasses all management processes, as well as the control of logistics 
activities and resource flows within urban areas. Although, the implementation of this multifaced concept necessitates a confluence of variables. The results show that stakeholder interaction and policy frameworks are essential factors in implementing city logistics measures. These predictor variables have a significant impact on solving problems and ensuring environmental sustainability. Environmental sustainability correlates significantly with city logistics measures and stakeholder participation in this study. As a result, we have accepted the hypotheses (H1, H2, and $\mathrm{H} 3$ ).

From our study of the currently reported efforts for city logistic and environmental sustainability modeling and the prospects still left unexploited, we draw the following conclusions. In the urban freight transportation system, urban traffic has received considerable attention thus far. Because many adverse problems associated with urban freight transport are noticeable at the traffic market, other segment such as transportation, commerce, so on and so forth have received relatively little attention from city logistics researchers. However, the sector of urban freight traffic is heavily reliant on demand-supply actions in trade and transportation markets, which will ensure environmental sustainability. As a result, understanding problems or the bidirectional relationship that exists between the variables measured generally requires an understanding of associated logistics processes, which usually entails a multi-faceted and multi-disciplinary approach, as advocated by (van Duin and Quak, 2007).

However, the city logistics approach is a sole stakeholder involvement operation that requires policy initiative and assistance. That said, policy varies from planning. The former is concerned with developing modern infrastructure (roadways, terminals, parking spaces, etc.) or traffic planning to improve urban goods movement and curtail environmental impacts. In contrast, the latter is concerned with enacting policy measures such as legislation, safety standards, or development projects to lessen adverse effects associated with urban goods movement. The standard policy measure linked to city logistics is vehicle regulation based on weight, size, and transport vehicle time. Therefore, policy measures and their implementation should consider perceptible and feasible preventive measures to city logistics challenges by ascertaining research data or application methods. Visser et al. (1999) concluded that the "Learning by Doing" approach to urban freight policy implementation was not well received in city logistics implementation activity. Other modeling efforts with a policy perspective by (Taniguchi \& Tamagawa, 2005) modulate a road network with implemented policy reforms, including truck bans and the tolling of urban expressways. This contextual issue is not adequately addressed in the articles reviewed on urban freight research. They frequently assume, implicitly or explicitly, that their technique solves all city logistics problems. At most, attention is paid to a specific problem in which a technique has been tested empirically, or the need to modify the guidelines taken into consideration when employing the technique to a different sort of problem.

Our study illustrates that more key variables, including the goal, stakeholder 
interaction, characteristics of their activities, policies, and available means for goal accomplishment, are critical when carrying out city logistic implementation. In future studies, more emphasis needs to be placed on positioning new contributions within such a framework.

\section{Future Research}

The research established a strong policy support for environmental sustainability. Since there is a statistical significant relationship between policies and environmental sustainability at $1 \%$ level than other explanatory variables. Although, the results show that policies play a crucial role in environmental sustainability. Further research can be conducted in other parts of Ghana to ascertain or test other variables such as technology, market-based initiatives, land use planning and eco-logistics awareness to establish its impact on environmental sustainability.

\section{Conflicts of Interest}

The authors declare no conflicts of interest regarding the publication of this paper.

\section{References}

Allen, J., Anderson, S., Browne, M., \& Jones, P. (2000). A Framework for Considering Policies to Encourage Sustainable Urban Freight Traffic and Goods/Service Flows: Summary Report. London.

Anand, N., Quak, H., van Duin, R., \& Tavasszy, L. (2012). City Logistics Modeling Efforts: Trends and Gaps-A Review. Procedia-Social and Behavioral Sciences, 39, 101-115. https://doi.org/10.1016/j.sbspro.2012.03.094

Awasthi, A., \& Proth, J.-M. (2006). A Systems-Based Approach for City Logistics Decision Making. Journal of Advances in Management Research, 3, 7-17. https://doi.org/10.1108/97279810680001242

Behrends, S. (2016). Recent Developments in Urban Logistics Research-A Review of the Proceedings of the International Conference on City Logistics 2009-2013. Transportation Research Procedia, 12, 278-287. https://doi.org/10.1016/j.trpro.2016.02.065

Benjelloun, A., \& Crainic, T. G. (2009). Trends, Challenges, and Perspectives in City Logistics. Buletinul AGIR, No. 4, 45-51.

Benjelloun, A., Crainic, T. G., \& Bigras, Y. (2010). Towards a Taxonomy of City Logistics Projects. Procedia-Social and Behavioral Sciences, 2, 6217-6228. https://doi.org/10.1016/j.sbspro.2010.04.032

Carbone, V., Rouquet, A., \& Roussat, C. (2017). The Rise of Crowd Logistics: A New Way to Co-Create Logistics Value. Journal of Business Logistics, 38, 238-252. https://doi.org/10.1111/jbl.12164

CIVITAS (2020). Smart Choices for Cities: Making Urban Freight Logistics More Sustainable. CIVITAS WIKI Consortium.

Cobbinah, P. B., Erdiaw-Kwasie, M. O., \& Amoateng, P. (2015). Africa's Urbanisation: Implications for Sustainable Development. Cities, 47, 62-72. https://doi.org/10.1016/j.cities.2015.03.013

Cobbinah, P. B., Poku-Boansi, M., \& Peprah, C. (2017). Urban Environmental Problems 
in Ghana. Environmental Development, 23, 33-46. https://doi.org/10.1016/j.envdev.2017.05.001

Crainic, T., Ricciardi, N., \& Storchi, G. (2009). Models for Evaluating and Planning City Logistics Transportation Systems. Transportation Science, 43, 432-454.

de Oliveira, G. F., \& de Oliveira, L. K. (2016). Stakeholder's Perceptions of City Logistics: An Exploratory Study in Brazil. Transportation Research Procedia, 12, 339-347. https://doi.org/10.1016/j.trpro.2016.02.070

Demir, E., Huang, Y., Scholts, S., \& Van Woensel, T. (2015). A Selected Review on the Negative Externalities of the Freight Transportation: Modeling and Pricing. Transportation Research Part E: Logistics and Transportation Review, 77, 95-114. https://doi.org/10.1016/j.tre.2015.02.020

Gatta, V., Marcucci, E., Delle Site, P., Le Pira, M., \& Carrocci, C. S. (2019). Planning with Stakeholders: Analysing Alternative Off-Hour Delivery Solutions via an Interactive Multi-Criteria Approach. Research in Transportation Economics, 73, 53-62. https://doi.org/10.1016/j.retrec.2018.12.004

Gatta, V., Marcucci, E., Nigro, M., Patella, S., \& Serafini, S. (2018). Public TransportBased Crowdshipping for Sustainable City Logistics: Assessing Economic and Environmental Impacts. Sustainability, 11, 145. https://doi.org/10.3390/su11010145

Kaiser, H. F. (1974). An Index of Factorial Simplicity. Psychometrika, 39, 31-36. https://doi.org/10.1007/BF02291575

Katsela, K., \& Browne, M. (2019). Importance of the Stakeholders' Interaction: Comparative, Longitudinal Study of Two City Logistics Initiatives. Sustainability, 11, 5844. https://doi.org/10.3390/su11205844

Keeble, B. R. (1988). The Brundtland Report: “Our Common Future”. Medicine and War, 4, 17-25. https://doi.org/10.1080/07488008808408783

Lagorio, A., Pinto, R., \& Golini, R. (2016). Research in Urban Logistics: A Systematic Literature Review. International Journal of Physical Distribution \& Logistics Management, 46, 908-931. https://doi.org/10.1108/IJPDLM-01-2016-0008

Le Pira, M., Marcucci, E., Gatta, V., Inturri, G., Ignaccolo, M., \& Pluchino, A. (2017). Integrating Discrete Choice Models and Agent-Based Models for Ex-Ante Evaluation of Stakeholder Policy Acceptability in Urban Freight Transport. Research in Transportation Economics, 64, 13-25. https://doi.org/10.1016/j.retrec.2017.08.002

Lebeau, P., Macharis, C., Van Mierlo, J., \& Janjevic, M. (2018). Improving Policy Support in City Logistics: The Contributions of a Multi-Actor Multi-Criteria Analysis. Case Studies on Transport Policy, 6, 554-563. https://doi.org/10.1016/j.cstp.2018.07.003

Lidasan, H. S. (2011). City Logistics: Policy Measures Aimed at Improving Urban Environment through Organization and Efficiency in Urban Logistics Systems in Asia. Transport and Communications Bulletin for Asia and the Pacific, No. 80, 84-99.

Likert, R. (1932). A Technique for the Measurement of Attitudes. Archives of Psychology, 22, 1-55.

Lindholm, M. E., \& Blinge, M. (2014). Assessing Knowledge and Awareness of the Sustainable Urban Freight Transport among Swedish Local Authority Policy Planners. Transport Policy, 32, 124-131. https://doi.org/10.1016/j.tranpol.2014.01.004

Lindholm, M., \& Behrends, S. (2012). Challenges in Urban Freight Transport PlanningA Review in the Baltic Sea Region. Journal of Transport Geography, 22, 129-136. https://doi.org/10.1016/j.jtrangeo.2012.01.001

Lindholm, M., \& Browne, M. (2013). Local Authority Cooperation with Urban Freight Stakeholders: A Comparison of Partnership Approaches. EJTIR, 13, 20-38. 
Marcucci, E., Gatta, V., \& Le Pira, M. (2018). Gamification Design to Foster Stakeholder Engagement and Behavior Change: An Application to Urban Freight Transport. Transportation Research Part A: Policy and Practice, 118, 119-132. https://doi.org/10.1016/j.tra.2018.08.028

Marcucci, E., Gatta, V., Marciani, M., \& Cossu, P. (2017). Measuring the Effects of an Urban Freight Policy Package Defined via a Collaborative Governance Model. Research in Transportation Economics, 65, 3-9. https://doi.org/10.1016/j.retrec.2017.09.001

Neghabadi, D. P., Samuel, K. E., \& Espinouse, M.-L. (2018). Systematic Literature Review on City Logistics: Overview, Classification and Analysis. International Journal of Production Research, 57, 865-887. https://doi.org/10.1080/00207543.2018.1489153

Obilor, E. I. M., \& Amadi, E. C. (2018). Test for Significance of Pearson's Correlation Coefficient. International Journal of Innovative Mathematics, Statistics \& Energy Policies, 6, 11-23.

OECD (2003). Delivering the Goods: 21st Century Challenges to Urban Goods Transport (p. 153). Paris: OECD. https://doi.org/10.1787/9789264102828-en

Oliveira, L., Barraza, B., Bertocini, B., Isler, C., Pires, D., Madalon, E., Lima, J., Vieira, J., Meira, L., Bracarense, L., Bandeira, R., Oliveira, R., \& Ferreira, S. (2018). An Overview of Problems and Solutions for Urban Freight Transport in Brazilian Cities. Sustainability, 10, 1233. https://doi.org/10.3390/su10041233

Österle, I., Aditjandra, P. T., Vaghi, C., Grea, G., \& Zunder, T. H. (2015). The Role of a Structured Stakeholder Consultation Process within the Establishment of a Sustainable Urban Supply Chain. Supply Chain Management: An International Journal, 20, 284-299. https://doi.org/10.1108/SCM-05-2014-0149

Pimentela, C., \& Alvelos, F. (2018). Integrated Urban Freight Logistics Combining Passenger and Freight Flows-Mathematical Model Proposal. Transportation Research Procedia, 30, 80-89. https://doi.org/10.1016/j.trpro.2018.09.010

Pustokhina, I., \& Pustokhin, D. (2019). City Logistics as an Element of Sustainable Urban Development: Car Sharing System in Russia. Russian Logistics Journal.

Quak, H., Balm, S., \& Posthumus, B. (2014). Evaluation of City Logistics Solutions with Business Model Analysis. Procedia-Social and Behavioral Sciences, 125, 111-124. https://doi.org/10.1016/j.sbspro.2014.01.1460

Quak, H., Lindholm, M., Tavasszy, L., \& Browne, M. (2016). From Freight Partnerships to City Logistics Living Labs-Giving Meaning to the Elusive Concept of Living Labs. Transportation Research Procedia, 12, 461-473. https://doi.org/10.1016/j.trpro.2016.02.080

Rubinia, L., \& Lucia, D. L. (2018). Governance and the Stakeholders' Engagement in City Logistics: The SULPiTER Methodology and the Bologna Application. Transportation Research Procedia, 30, 255-264. https://doi.org/10.1016/j.trpro.2018.09.028

Russo, F., \& Comi, A. (2016). Urban Freight Transport Planning towards Green Goals: Synthetic Environmental Evidence from Tested Results. Sustainability, 8, 381. https://doi.org/10.3390/su8040381

Rześny-Cieplińska, J., \& Szmelter-Jarosz, A. (2020). Environmental Sustainability in City Logistics Measures. Energies, 13, 1303. https://doi.org/10.3390/en13061303

Rześny-Cieplińska, J., \& Szmelter-Jarosz, A. (2021). Stakeholders' Analysis of Environmental Sustainability in Urban Logistics: A Case Study of Tricity, Poland. Energies, 14, 1274. https://doi.org/10.3390/en14051274

Sarbah, A., Fokouh, S. K., Obeng, E., \& Quaye, I. (2014). Managing City Logistics in Ghana: Trends, Developments and Implications to City Dwellers. International Journal 
of Economics, Commerce and Management, 2, 1-34.

Schaltegger, S., Lüdeke-Freund, F., \& Hansen, E. G. (2012). Business Cases for Sustainability: The Role of Business Model Innovation for Corporate Sustainability. International Journal of Innovation and Sustainable Development, 6. https://doi.org/10.1504/IJISD.2012.046944

Stathopoulos, A., Valeri, E., \& Marcucci, E. (2012). Stakeholder Reactions to Urban Freight Policy Innovation. Journal of Transport Geography, 22, 34-45.

https://doi.org/10.1016/j.jtrangeo.2011.11.017

Taherdoost, H. (2016). Validity and Reliability of the Research Instrument: How to Test the Validation of a Questionnaire Survey in a Research. International Journal of Academic Research in Management (IJARM), 5, 28-36.

https://doi.org/10.2139/ssrn.3205040

Taniguchi, E. (2014). Concepts of City Logistics for Sustainable and Liveable Cities. Procedia-Social and Behavioral Sciences, 151, 310-317.

https://doi.org/10.1016/j.sbspro.2014.10.029

Taniguchi, E., \& Tamagawa, D. (2005). Evaluating City Logistics Measures Considering the Behavior of Several Stakeholders. Journal of the Eastern Asia Society for Transportation Studies, 6, 3062-3076.

Taniguchi, E., \& Thompson, E. (2018). City Logistics 3: Towards Sustainable and Liveable Cities. Great Britain \& United States: ISTE Ltd. and John Wiley \& Sons, Inc. https://doi.org/10.1002/9781119425472

Taniguchi, E., Thompson, R. G., \& Yamada, T. (2012). Emerging Techniques for Enhancing the Practical Application of City Logistics Models. Procedia-Social and Behavioral Sciences, 39, 3-18. https://doi.org/10.1016/j.sbspro.2012.03.087

Taniguchi, E., Thompson, R. G., \& Yamada, T. (2014). Recent Trends and Innovations in Modelling City Logistics. Procedia-Social and Behavioral Sciences, 125, 4-14. https://doi.org/10.1016/j.sbspro.2014.01.1451

Taniguchi, E., Thompson, R. G., Yamada, T., \& Van Duin, R. (2001). City Logistics: Network Modelling and Intelligent Transport Systems. Oxford: Elsevier.

UN (2019). The Sustainable Development Goals Report 2019. New York, NY.

Valiantis, M. (2014). Sustainable Urban Transport. Hauppauge, NY: Nova Science Publishers, Inc.

van Duin, J. H. R., \& Quak, H. J. (2007). City Logistics: A Chaos between Research and Policy Making? A Review. WIT Transactions on the Built Environment, 96, 135-146. https://doi.org/10.2495/UT070141

Van Duin, R., Wiegmans, B., Tavasszy, L., Hendriks, B., \& He, Y. Z. (2019). Evaluating New Participative City Logistics Concepts: The Case of Cargo Hitching. Transportation Research Procedia, 39, 565-575. https://doi.org/10.1016/j.trpro.2019.06.058

Visser, J., van Binsbergen, A. J., \& Nemoto, T. (1999). Urban Freight Transport Policy and Planning. First International Symposium on City Logistics, Cairns, Australia, July 1999, 39-69.

WHO (2018). Drinking Water, Sanitation and Hygiene in Schools (p. 84). WHO/UNICEF.

Witkowski, J., \& Kiba-Janiak, M. (2012). The Role of Stakeholders in a Developing Reference Model of City Logistics versus the Quality of Citizens' Life. Logistyka, 2, 10651076.

Yamane, Y. (1967). Mathematical Formulae for Sample Size Determination.

Zenezini, G., van Duin, J. H. R., Tavasszy, L., \& De Marco, A. (2018). Stakeholders' Roles 
for Business Modeling in a City Logistics Ecosystem: Towards a Conceptual Model. In E. Taniguchi, \& R. G. Thompson (Eds.), City Logistics 2 (pp. 39-58). Hoboken, NJ: John Wiley \& Sons, Inc. https://doi.org/10.1002/9781119425526.ch3

Zinbarg, R. E., Revelle, W., Yovel, I., \& Li, W. (2005). Cronbach's $\alpha$, Revelle's $\beta$, and McDonald's $\omega_{H}$ : Their Relations with Each Other and Two Alternative Conceptualizations of Reliability. Psychometrika, 70, 123-133.

https://doi.org/10.1007/s11336-003-0974-7 